\title{
Occurrence of non-native species and their potential impact on plant communities in protected areas in the Brazilian Amazon region
}

\author{
Lana Cynthia Silva Magalhães ${ }^{1}$, Silvia Renate Ziller $^{2}$ \& Maria Clara Silva-Forsberg ${ }^{1}$ \\ 1. Laboratory of Applied Ecology, Normal Superior School, Amazonas State University, 69050-010, Manaus, Brazil; \\ lmagalhaes@uea.edu.br, cforsberg@uea.edu.br \\ 2. Hórus Institute of Environmental Development and Conservation, 88.040-970, Florianópolis, Brazil; \\ sziller@institutohorus.org.br
}

Received 21-I-2020. Corrected 30-III-2020. Accepted 14-VII-2020.

\begin{abstract}
Introduction: There is a large information gap on the occurrence of non-native species and their impacts on native biodiversity in the Amazon region in Brazil. Objective: The objective of this study was to characterize the floristic composition of a protected area in Manaus, Amazonas, and assess the potential impact of non-native invasive species. Methods: A floristic survey was carried out in 30 plots measuring $20 \mathrm{x}$ $20 \mathrm{~m}$ with $1 \times 1 \mathrm{~m}$ subplots. The estimated parameters were density, frequency, dominance, Importance Value Index (IVI), and Environmental Impact of Non-Native Species (IIAE). Results: In total, 8 out of 264 species registered in the tree-shrub layer were not native. A total of 61 species were identified in the herbaceous layer, five of which were non-native. The impact is estimated based on the highest abundance of species of non-native species. Conclusions: The presence of non-native species in the study area is an indication of a potential impact on biodiversity and ecosystem functions.
\end{abstract}

Key words: biological invasions; invasive species; abundance; index of environmental impact of non-native species; phytosociology.

Silva Magalhães, L.C., Ziller, S.R., \& Silva-Forsberg, M.C. (2020). Occurrence of non-native species and their potential impact on plant communities in protected areas in the Brazilian Amazon region. Revista de Biología Tropical, 68(4), 1039-1048.

The destruction of habitats due to deforestation and fragmentation causes changes that affect biological communities (Primack \& Rodrigues, 2001). Due to such changes in environmental conditions, non-native species may find opportunities to establish, achieve high reproduction and dispersal rates, become invasive and displace native species in a process known as biological invasion (Moro et al., 2012). By occupying niches previously used by native species, non-native species can cause local extinctions and compromise ecosystem functioning (Ziller, 2006).

Despite the recognized risk of biological invasions in natural areas, the scientific evidence of impact remains modest, even for non-native invasive species considered aggressive (Hulme et al., 2013). Measuring abundance is the most feasible option to quantify the impact of invasive species (Bradley, 2013; Ricciardi, Hoopes, Marchetti, \& Lockwood, 2013). In addition, abundance is considered a key variable in the biological invasion process (Williamson \& Fitter, 1996) because the advantage of monopolizing space in the community to the detriment of native species is directly related to impact (Hedja, Pyšek, \& Jarošik, 2009).

Another alternative to measure impact is assessing phytosociological parameters 
(density, frequency, dominance of the importance value index - IVI) (Andrade, Fabricante, \& Oliveira, 2009; Andrade, Fabricante, \& Oliveira, 2011). The possibility of ranking species in order of social importance can determine the impact caused by non-native species, because a decrease in the importance value index of native species is one of the main consequences of biological invasion (Parker et al., 1999).

Although biological invasions in tropical forests have been scarcely studied, it is clear that non-native invasive species may become dominant in such habitats (Fine, 2002). Several non-native species have been able to establish and invade forest fragments in the Amazon region (Laurance \& Vasconcelos, 2009). There are 31 non-native plant species registered for the Amazon region, eight of which are considered of high risk for having invasive potential and being present in three or more Amazonian states (Silva \& Silva-Forsberg, 2015).

Considering the growing threat of nonnative species to ecosystems and native biodiversity in the Amazon region, the aim of this study was to characterize the floristic composition of a protected forest fragment in the Sumauma State Park, Manaus, Amazonas, Brazil, and assess the potential impact of nonnative species on the plant community as a case study to introduce a larger research agenda in the Brazilian Amazon region.

\section{MATERIALS AND METHODS}

Study area: A floristic survey was conducted in the Sumauma State Park, a 52.57 ha forest fragment located in northern Manaus, Amazonas, Brazil, lying between geographic coordinates $03^{\circ} 01^{\prime} 50^{\prime \prime}$ - 032'26” S \& 59॰58'59" - 59 58’31” W (Fig. 1). It has humid equatorial climate with an average annual temperature of $26.7^{\circ} \mathrm{C}$. Relative humidity is $80 \%$ and the average annual precipitation is $2286 \mathrm{~mm}$. Gleysols prevail in the area, but part of the soils in the park have been altered due to the construction of a housing complex (Amazonas, 2009).

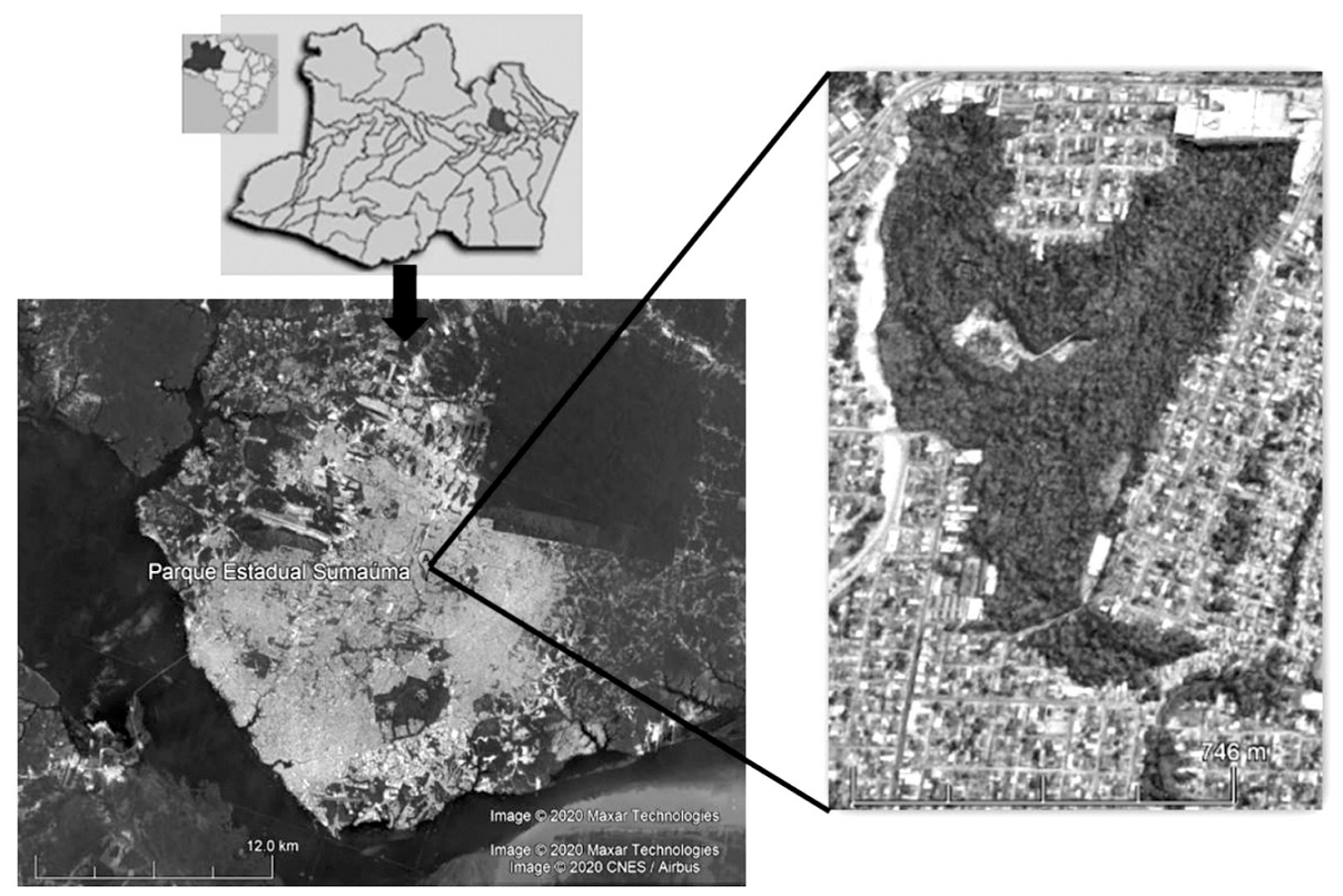

Fig. 1. Sumauma State Park, one of the forest fragments in the city of Manaus, Amazonas, Brazil. Taken from Google Earth and adapted by the authors. 
A vegetation survey was carried out by establishing thirty $20 \times 20 \mathrm{~m}$ plots (MuellerDombois \& Ellenberg, 1974), totaling 1.2 ha as recommended in phytosociological studies involving tree species in tropical forests (Kersten \& Galvão, 2011; Moro \& Martins, 2011). Two layers were considered, tree-shrub and herbaceous. All individuals in the tree-shrub layer with diameter at breast height $(\mathrm{DBH})$ $\geq 2.5 \mathrm{~cm}$ were measured at a $1.30 \mathrm{~m}$ height above the ground in all $20 \times 20 \mathrm{~m}$ plots. Trees with buttresses or anomalies (damage or deformities) were measured above such features. Individuals with multiple trunks were considered single trees and measured below trunk ramifications at ground level (Moro \& Martins, 2011). All individuals in the herbaceous layer having between $10 \mathrm{~cm}$ and $1 \mathrm{~m}$ in height were measured in 1 x $1 \mathrm{~m}$ subplots (Munhoz \& Araújo, 2011) established on the left side of the $20 \times 20 \mathrm{~m}$ plots. For clonal species, such as grasses, every bush was considered one individual (Costa, 2006).

Considering that the study area is a forest fragment located in an urban landscape, that biological invasions often start on the forest edges (Santana \& Encinas, 2008) and that edge effects are felt up to $100 \mathrm{~m}$ into the forest (Laurance \& Bierregaard, 1997), the plots were systematically distributed. Fifteen plots were allocated $2 \mathrm{~m}$ from the park fence, with 300 $\mathrm{m}$ between each plot, considered a border area under the influence of environmental changes resulting from fragmentation. The remaining plots were distributed in the central area of the park, $120 \mathrm{~m}$ from the border (forest edge) in order to minimize the edge effects, with a distance of 120-150 m between the plots.

Plants were initially identified in the field with the assistance of a taxonomist. However, in order to correctly identify the species, parts of plants, preferably fertile, and herbs with roots were collected. The material collected was dried from 48 to 72 hours in a plant specimen drier at $60{ }^{\circ} \mathrm{C}$. After herborization, identification was confirmed by comparison with exsiccates in the Amazon National Research Institute - INPA herbarium.

Specialized literature (Ribeiro et al., 1999; Souza \& Lorenzi, 2008) and the online databases of the Botanical Garden of Rio de Janeiro for native species and the Horus Institute National Invasive Alien Species Database for non-native invasive species were consulted to determine the origin of the species registered in the survey. The fertile botanical material was deposited in the INPA herbarium, while the sterile material was stored in the Amazonas State University Laboratory of Applied Ecology.

Analysis of phytosociological parameters: Phytosociological parameters density, frequency, dominance and importance value index were estimated based on Mueller-Dombois and Ellenberg (1974). Only the density, frequency and importance value index parameters were considered for plants in the herbaceous layer (Mueller-Dombois \& Ellenberg, 1974; Munhoz \& Araújo, 2011). Calculations were performed employing Microsoft Excel - Windows 2007 software, using the formulas proposed by Moro and Martins (2011).

Measurement of impacts by non-native species: In addition to the phytosociological parameters, the number of individuals recorded (abundance) in the herbaceous and tree-shrub layer was taken as a basis for determining the impact of non-native species on native plants (Bradley, 2013; Ricciardi et al., 2013). Impact measurements of the tree-shrub layer were complemented by the Index of Environmental Impact of Non-Native Species (IIAE) proposed by Santana and Encinas (2008), which ranges from 1 to -1 . Numbers closer to the negative value correspond to greater degrees of invasion in each plot (Andrade et al., 2009; Santana \& Encinas, 2008): IIAE = (Pexotic - Pnative $)$ $/$ Ptotal, where: Pexotic $=$ IVI value of nonnative plants in the plot; Pnative $=$ IVI value of native plants in the plot; Ptotal $=$ total IVI value $(\mathrm{IVI}=300)$.

\section{RESULTS}

Characterization and phytosociological aspects of the tree-shrub layer: The tree-shrub layer included 1710 individuals in 48 families, 155 genera and 264 species. 
TABLE 1

List of species in descending order of Importance Value Index in the tree-shrub layer

\begin{tabular}{lccccc}
\multicolumn{1}{c}{ Species } & $\mathrm{N}$ & $\mathrm{DRe}(\%)$ & DoRe $(\%)$ & FRe $(\%)$ & IVI (\%) \\
Tapirira guianensis Aubl. & 93 & 5.44 & 6.58 & 3.15 & 15.17 \\
Ficus maxima Mill. & 98 & 5.73 & 4.96 & 3.31 & 14.01 \\
Euterpe precatoria Mart. & 83 & 4.85 & 4.94 & 2.52 & 12.32 \\
Piper aduncum L. & 140 & 8.19 & 1.84 & 2.21 & 12.24 \\
Spondias mombin L. & 26 & 1.52 & 7.68 & 1.26 & 10.47 \\
Euterpe oleracea Mart. & 49 & 2.87 & 4.6 & 0.47 & 7.942 \\
Inga paraensis Ducke & 32 & 1.87 & 2.25 & 1.89 & 6.017 \\
Guatteria olivacea Ruiz \& Pav. & 26 & 1.52 & 2.33 & 1.74 & 5.584 \\
Cecropia sciadophylla Mart. & 20 & 1.17 & 2.43 & 1.26 & 4.86 \\
Ceiba pentandra (L.) Gaertn. & 6 & 0.35 & 3.28 & 0.47 & 4.099 \\
Inga edulis Mart. & 23 & 1.35 & 1.33 & 1.42 & 4.097 \\
Eschweilera atropetiolata S. A. Mori & 4 & 0.23 & 2.97 & 0.47 & 3.673 \\
Croton lanjouwianus Jabl. & 9 & 0.53 & 2.61 & 0.32 & 3.451 \\
Siparuna guianensis Aubl. & 28 & 1.64 & 0.38 & 1.42 & 3.433 \\
Trattinnickia glaziovii Swart. & 1 & 0.06 & 3.12 & 0.16 & 3.334 \\
Anomalocalyx uleanus (Pax \& K. Hoffm.) Ducke & 32 & 1.87 & 0.79 & 0.63 & 3.288 \\
Astrocaryum munbaca Mart. & 28 & 1.64 & 0.29 & 1.26 & 3.193 \\
Mauritia aculeata Kunth & 22 & 1.29 & 1.29 & 0.47 & 3.054 \\
Ocotea longifolia Kunth & 31 & 1.81 & 0.24 & 0.63 & 2.68 \\
Subtotal & 765 & 44.8 & 54.9 & 26.2 & 125.9 \\
Other species & 945 & 55.2 & 45.1 & 73.8 & 174.1 \\
Total & 1710 & 100 & 100 & 100 & 300 \\
\hline
\end{tabular}

N: number of individuals; DRe: Relative Density of the species; DoRe: Relative Dominance of the species; FRe: Relative Frequency of the species; IVI: Importance Value Index.

The most representative families in number of species were Fabaceae (37), Annonaceae (16), Moraceae (14), Myristicaceae (14) and Arecaceae, Burseraceae, Lecythidaceae and Myrtaceae (12 each), which accounted for 49 $\%$ of the species in the plots.

The DBH of $1271(74.5 \%)$ trees ranged from 2.5 to $10 \mathrm{~cm}$. As diameter values increased, the number of individuals decreased. Only 61 individuals had DBH $>30 \mathrm{~cm}$, and the largest tree registered was Trattinnickia glaziovii. Only one tree represented this species, with a DBH of $89.8 \mathrm{~cm}$.

The species with the highest relative densities were: Piper aduncum (8.19\%), Ficus maxima (5.73\%), Tapirira guianensis (5.44 $\%)$, Euterpe precatoria (4.85\%) and Euterpe oleracea $(2.87 \%)$. The highest frequency values were registered for F. maxima, found in
23 plots, and T. guianensis, found in 21. The most dominant species were: Spondias mombin (7.68 \%), T. guianensis (6.58 \%), F. maxima (4.96\%), E. precatoria (4.94\%) and E. oleracea $(4.6 \%)$ (Table 1$)$.

The species with the highest social contribution was $T$. guianensis $(15.17 \%)$. Although it did not represent the largest number of individuals, it obtained high frequency and dominance values. Species F. maxima $(14.01 \%), E$. precatoria $(12.32 \%)$, P. aduncum (12.24\%) and $S$. mombin $(10.47 \%)$ represented the highest importance values in the community. All 20 species with the highest importance value indices are native to the Amazon region (Table 1).

A total of 37 non-native plants were registered in the tree-shrub layer, distributed in the following species: Artocarpus heterophyllus Lam. - jackfruit (4), Carica papaya L. - papaya 
(6), Leucaena leucocephala (Lam.) de Wit leadtree (12), Mangifera indica L. - mango (3), Persea americana Mill. - avocado (1), Psidium guajava L. - guava (6), Ricinus communis L. - castor bean (3), and Syzygium cumini (L.) Skeels - olive (2).

Characterization and phytosociological aspects of the herbaceous layer: The herbaceous layer was sampled in 1 x $1 \mathrm{~m}$ subplots including plants between $10 \mathrm{~cm}$ and $1 \mathrm{~m}$ in height. A total of 237 individuals were registered in 35 families and 61 species. The most representative families were: Fabaceae, with seven species, Poaceae and Arecaceae, with four species each. The species with the largest number of individuals (31) was non-native grass Megathyrsus maximus, found in two plots. Other Poaceae representatives were also relevant: Pariana sp., a genus native to the Amazon region, of which 30 individuals were found, with higher frequency compared to the invasive grass, distributed in four plots; and Ichnanthus panicoides, with 17 individuals found in only one plot. Pariana sp. was the species with higher social contribution, followed by M. maximus, Alocasia macrohrrizos, I. panicoides and Piper peltatum (Table 2).

A total of 52 non-native individuals were found in the herbaceous layer, representing $22 \%$ of the total of individuals. They belong to five species: M. maximus - Guinea grass (31), Alocasia macrorrhizos - elephant ear taro (14), Dieffenbachia seguine - dumbcane (5), A. heterophyllus - jackfruit (1) and Ricinus communis - castor bean (1). A. heterophyllus and $R$. communis plants were also recorded in the tree-shrub layer, which confirms their

TABLE 2

List of species in descending order of IVI in the herbaceous layer

\begin{tabular}{|c|c|c|c|c|c|}
\hline Species & Origin & $\mathrm{N}$ & DRe $(\%)$ & $\operatorname{FRe}(\%)$ & IVI $(\%)$ \\
\hline Pariana sp. Aubl. & $\mathrm{Na}$ & 30 & 12.7 & 4.94 & 17.6 \\
\hline Megathyrsus maximus (Jacq.) B.K.Simon \& S.W.L.Jacobs & $\mathrm{Nn}$ & 31 & 13.1 & 2.47 & 15.55 \\
\hline Alocasia macrorrhizos (L.) G.Don & $\mathrm{Nn}$ & 14 & 5.91 & 7.41 & 13.31 \\
\hline Ichnanthus panicoides P.Beauv. & $\mathrm{Na}$ & 17 & 7.17 & 1.23 & 8.408 \\
\hline Piper peltatum L. & $\mathrm{Na}$ & 12 & 5.06 & 2.47 & 7.532 \\
\hline Piper manausense Yunck & $\mathrm{Na}$ & 10 & 4.22 & 2.47 & 6.689 \\
\hline Plumbago scandens L. & $\mathrm{Na}$ & 9 & 3.8 & 1.23 & 5.032 \\
\hline Tapirira guianensis Aubl. & $\mathrm{Na}$ & 9 & 3.8 & 1.23 & 5.032 \\
\hline Ficus maxima Mill. & $\mathrm{Na}$ & 6 & 2.53 & 2.47 & 5.001 \\
\hline Lindsaea lancea var. falcata Dryand & $\mathrm{Na}$ & 6 & 2.53 & 2.47 & 5.001 \\
\hline Oenocarpus bataua Mart. & $\mathrm{Na}$ & 3 & 1.27 & 3.7 & 4.97 \\
\hline Dieffenbachia seguine (Jacq.) Schott & $\mathrm{Nn}$ & 5 & 2.11 & 1.23 & 3.344 \\
\hline Olyra sp. L. & $\mathrm{Na}$ & 5 & 2.11 & 1.23 & 3.344 \\
\hline Rudgea sp. Salisb. & $\mathrm{Na}$ & 5 & 2.11 & 1.23 & 3.344 \\
\hline Astrocaryum aculeatum G.Mey & $\mathrm{Na}$ & 2 & 0.84 & 2.47 & 3.313 \\
\hline Derris amazonica Killip. & $\mathrm{Na}$ & 2 & 0.84 & 2.47 & 3.313 \\
\hline Oenocarpus bacaba Mart. & $\mathrm{Na}$ & 2 & 0.84 & 2.47 & 3.313 \\
\hline Rapatea paludosa Aubl. & $\mathrm{Na}$ & 2 & 0.84 & 2.47 & 3.313 \\
\hline Siparuna guianensis Aubl. & $\mathrm{Na}$ & 2 & 0.84 & 2.47 & 3.313 \\
\hline Heliconia acuminate L.C.Rich. & $\mathrm{Na}$ & 4 & 1.69 & 1.23 & 2.922 \\
\hline Subtotal & & 176 & 74.3 & 49.4 & 123.6 \\
\hline Other species & & 61 & 25.7 & 50.6 & 76.4 \\
\hline Total & & 237 & 100 & 100 & 200 \\
\hline
\end{tabular}

$\mathrm{N}$ : number of individuals; DRe: Relative density of the species; FRe: Relative Frequency of the species; IVI: Importance Value Index; Na: Native, Nn: Non-native). 
establishment, with probable consequences of further invasion.

The potential impact of non-native species based on abundance and phytosociology: In total, 89 individuals distributed in 11 species were registered. The most abundant species were M. maximus (31), A. macrorrhizos (14), L. leucocephala (12), P. guajava (6) and A. heterophyllus (5). Non-native species were found in 10 of the 30 plots, of which only two occurred in the inner area of the park, demonstrating a high concentration of non-native plants along the edges, in close proximity to the surrounding backyards.

The species with the highest IVI was Pariana sp., native to the Amazon region, followed by the non-native $M$. maximus, which gained importance due to their high dominance. $A$. macrorrhizos had the third largest IVI due to density and frequency. It was found in six plots, one of which in the inner area of the park, which implies greater distribution than other herbaceous non-native species. Another non-native species, D. seguine, also showed a high IVI, standing out among the 15 most important species.

The most abundant non-native species recorded in the tree-shrub layer was L. leucocephala, present in forest gaps far from the borders of the park. However, despite being the non-native species with the largest number of individuals, its low frequency and dominance compared to native species resulted in a low IVI position, $73^{\text {rd }}$, in the community. This is due to the restricted amount of open areas in the park, which is mostly covered in forest, as L. leucocephala is a shade-intolerant pioneer species. The lower importance values of other non-native species do not exclude potential impacts, which were measured by the index of environmental impact of non-native species.

The Index of Environmental Impact of Non-Native Species for the tree-shrub layer: Of the ten plots with non-native plants, seven included woody invasive species with $\mathrm{DBH} \geq$ $2.5 \mathrm{~cm}$ in the tree-shrub layer. The IIAE (Index of Environmental Impact of Non-Native Species) complements the values of abundance and phytosociological parameters to estimate potential impacts. The results of IIAE range from 0.929 to 0.556 (Fig. 2).

The lowest IIAE value, representing greater environmental impact, was recorded for plot 10 , located on the forest edge. The smallest number of native (37) and the second largest number of non-native plants (9) were found in this area. In the same plot, the abundance of non-native $P$. guajava (4) stands out, as only the native $P$. aduncum was represented by a larger number of plants (14). The largest number of non-native individuals was found in plot 22 , located in the inner area of the park, with 12 L. leucocephala plants and one C. papaya

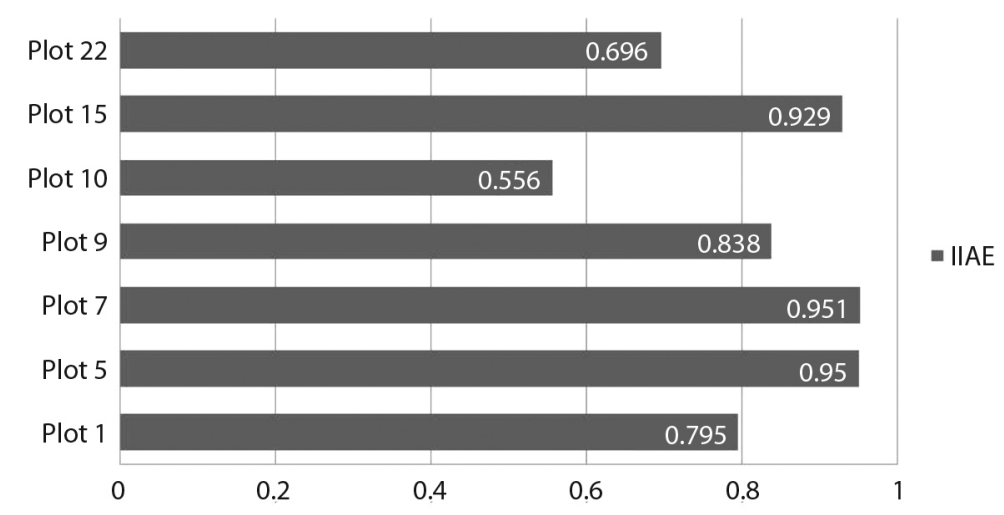

Fig. 2. Impact recorded in the plots with occurrence of non-native species in the tree-shrub layer. 
plant among 62 natives. The IIAE in this plot was 0.696 , the second lowest value.

\section{DISCUSSION}

The number of species identified in this study was larger than in the study of Pinheiro et al., (2010), who conducted a floristic survey in the Sumauma State Park which identified 1176 individuals in 196 species with a DBH $\geq 5 \mathrm{~cm}$. The diametric structure of the plant community showed that the majority of DBH measurements ranged from 2.5 to $5 \mathrm{~cm}$, which indicates an initial stage of forest regeneration. As diameter classes increased, the number of individuals decreased, a pattern known as the "inverted J" curve, frequently observed in secondary forests or in early successional stages (Oliveira \& Amaral, 2004).

Most plants of these eleven non-native species were recorded in the plots along the borders of the park. This result was expected, since fragmented habitats with high levels of anthropogenic disturbance and impact are more susceptible to biological invasion (Ziller, 2000; Sax et al., 2007; Laurance \& Vasconcelos, 2009).

The dominance of non-native fruit trees such as A. heterophyllus, P. guajava, P. americana, $M$. indica, S. cumini and C. papaya can be explained by their presence in the backyards of houses in the vicinity. These areas are important sources of non-native species that can facilitate dispersal toward protected areas (Ziller, 2006). Among the non-native species found, only $C$. papaya has no record of invasion in Brazil or in other countries. The other species are considered invasive in some Brazilian biomes, but only L. leucocephala had already been registered for the Amazon region (The Horus Institute National Invasive Alien Species Database, 2017).

Understanding the biological traits of plants is key to understanding impact (D'Antonio \& Kark, 2002). Vegetative reproduction and seed dispersal are factors related to the species' ability to colonize, compete and spread throughout an area. Among the herbaceous species registered, M. maximus, D. seguine and A. macrorrhizos are propagated vegetatively, while the last two have tubers that can remain in the soil for months until they find the appropriate conditions to develop (CABI, 2014). Dieffenbachia seguine was observed along forest borders, in partial shade, which may imply that it will not invade denser forest due to light requirements.

Grass M. maximus and tree L. leucocephala produce seeds that are dispersed by the wind. Anemochoric plants exert more significant impacts on the richness of species (Pyšek et al., 2012) and can reach areas farther from the site of introduction in open ecosystems or degraded areas. These two species were abundant in the plots where they occurred. These plots represented degraded areas where a decrease in the number of native individuals was observed in comparison with plots inside the forest.

Invasion by L. leucocephala is facilitated in open ecosystems and degraded areas where they dominate and prevent the establishment of native species (Costa \& Durigan, 2010). During the floristic survey, clusters of L. leucocephala and $A$. heterophyllus individuals were observed in various parts of the park outside the study's plots. The reason why L. leucocephala is not more abundant or dominant is that most of the area is covered in forest, and the species is not shade-tolerant.

A. heterophyllus produces fruits and seeds with high germination and growth rates. In the state of Rio de Janeiro, Southeastern Brazil, the jackfruit has invaded many areas, including protected areas such as the Tijuca National Park, where they prevent the development of native species as they compete for soil nutrients and shading (Siqueira, 2006). P. guajava, of which six individuals were observed, is found throughout Brazil (Horowitz, Martins, \& Machado, 2007) and is invasive in several ecosystems, mostly in degraded forest areas (The Horus Institute National Invasive Alien Species Database, 2017).

$M$. indica is invasive in some semiarid areas in Northeastern Brazil, where it may impact native species by attracting animals 
to feed on its large fruit. This behavior reduces the consumption of native fruits, and consequently causes the dispersal of native species (Leão, Almeida, Dechoum, \& Ziller, 2011). S. cumini is scattered throughout Brazil (Siqueira, 2006), preferably invading secondary forests but also coastal dune ecosystems (The Horus Institute National Invasive Alien Species Database, 2017). Competition with native species hinders regeneration, interfering in successional patterns. Although P. americana is present in the Northeastern, Southeastern, Southern and Central-Western regions of Brazil, there are no records of invasion in Brazil (Sampaio \& Schmidt, 2013).

M. maximus displaces and replaces native vegetation, causing changes to the ecosystems (CABI, 2014). Overall, African grasses introduced in Brazil, especially species Urochloa and Melinis minutiflora (Pivello, 2011), outcompete native herbaceous populations and may lead to local extinction and loss of biodiversity. These are considered the most aggressive invasive species in the Brazilian Cerrado (tropical savanna) (Pivello, 2011).

The two species of family Araceae, $A$. macrorrhizos and D. seguine, have a similar behavior regarding invasion and impact, with a high capacity of vegetative reproduction and regrowth from tubers. They can displace native species by competing for space and resources, reducing populations (CABI, 2014).

Although non-native species were not registered in most plots, probably due to a denser forest cover, their presence in the area and IIAE values in some plots suggest an ongoing biological invasion process that tends to be aggravated over time, creating a risk of higher impact. The IIAE values in the Sumauma State Park expressed greater impact from non-native species than those recorded in areas close to the household waste deposit in some areas in Brasilia and Goiania, where values ranged from 0.995 to 0.998 (Santana \& Encinas, 2008). When studying the impact of areas dominated by Prosopis juliflora (Sw.) DC. in Caatinga (shrubland), Andrade et al., (2009) recorded negative values -0.635 to -0.637 , which demonstrates relevant impact caused by this species.

In another study in the Caatinga on $P$. juliflora, along the bank of the Paraiba river, the impact index value of non-native species (IIAE) was 0.4 , i.e., $40 \%$ of the area was occupied by the species (Fônseca, Albuquerque, Leite, \& Lira, 2016). In this study, 4 plots obtained an IIAE below 0.8 , which is an indicator of severe environmental problems according to Andrade et al. (2010).

Considering IIEA values for the plots and the abundance of species such as L. leucocephala, A. heterophyllus, M. maximus, D. seguine and A. macrorrhizos, already acknowledged as invasive, it is possible to infer on the quantification of impacts. In line with that, the biological characteristics of these species facilitate their spreading and consequential impacts, which indicates the need for the control and/or eradication of these species.

Our study's results show that the presence of non-native species have the potential to impact the native biodiversity of the Sumauma State Park, and that distinct species are invading open areas and forests. Further studies in other protected areas in the Amazon region are required to fill the current information gap on which non-native species are present, where they are invading and what impacts they may cause. Early detection is key for eradication, and there is no doubt that existing populations will further reproduce and increase locally, as well as spread to new areas as opportunities arise and propagules are transported beyond current locations. Lists of non-native invasive species must be compiled to provide reference for regulations, policies and control programs in the region, subsidized by more research and awareness in this subject area.

Ethical statement: authors declare that they all agree with this publication and made significant contributions; that there is no conflict of interest of any kind; and that we followed all pertinent ethical and legal procedures and requirements. All financial sources are fully and clearly stated in the acknowledgements 
section. A signed document has been filed in the journal archives.

\section{ACKNOWLEDGMENTS}

This study was supported by the Foundation for the Support of Research in the State of Amazonas - FAPEAM, Notice No. 04/2012 - JCA - Protected Areas and Master program scholarship to the first author. The authors would like to thank valuable partners Daniel Praia, José Luciano Ventura, Antonio Tavares and Andréia Ferreira.

\section{RESUMEN}

Presencia de especies no nativas y su impacto potencial en comunidades de plantas de áreas protegidas en la Amazonía brasileña. Introducción: Existe un gran vacío de información sobre especies exóticas y sus impactos sobre la biodiversidad nativa en la región amazónica de Brasil. Objetivo: Este estudio tuvo como objetivo caracterizar la composición florística de un área protegida en Manaos, Amazonas, y evaluar el impacto potencial de las especies no nativas. Métodos: Se realizó un inventario florístico en 30 parcelas de 20 × $20 \mathrm{~m}$, con subparcelas de 1 x $1 \mathrm{~m}$. Los parámetros estimados fueron: densidad, frecuencia, predominancia, Índice de Valor de Importancia (IVI) e Impacto Ambiental de Especies no Nativas (IIAE). Resultados: En total, 8 de las 264 especies registradas en el estrato arbustivo no son nativas. Un total de 61 especies fueron identificadas en el estrato herbáceo, cinco de las cuales no son nativas. El impacto se estimó con base en la más alta abundancia de las especies de hierbas no nativas. Conclusiones: La presencia de especies no nativas en el área es un indicador de impactos potenciales sobre la biodiversidad y las funciones del ecosistema.

Palabras clave: invasiones biológicas; especies invasoras; abundancia; índice de impacto ambiental de especies no nativas; fitosociología.

\section{REFERENCES}

Amazonas (2009). Plano de gestão do Parque Estadual Sumaúma. Série Técnica Planos de Gestão. Manaus, Brasil: Secretária de Estado de Meio Ambiente e Desenvolvimento Sustentável do Amazonas.

Andrade, L.A., Fabricante, J.R., \& Oliveira, F.X. (2009). Invasão biológica por Prosopis juliflora (Sw.) DC. (Fabaceae): impactos sobre a diversidade e a estrutura do componente arbustivo-arbóreo da Caatinga no estado do Rio Grande do Norte, Brasil. Acta Botanica Brasilica, 23, 935-943.

Andrade, L.A., Fabricante, J.R., \& Oliveira, F.X. (2011). Impactos da invasão de Prosopis juliflora (sw.) DC. (Fabaceae) sobre o estrato arbustivo-arbóreo em áreas de Caatinga no estado da Paraíba, Brasil. Acta Scientiarum, 32, 249-255.

Bradley, B. (2013). Distribution models of invasive plants over-estimate potential impact. Biological Invasions, 15(7), 1417-1429.

CABI. (2014). Invasive Species Compendium. Retrieved from https://www.cabi.org/isc/search/index

Costa, F.R. (2006). Mesoscale Gradients of Herb Richness and Abundance in Central Amazonia. Biotropica, 38(6), 711-717.

Costa, J.N., \& Durigan, G. (2010). Leucaena leucocephala (Lam.) de Wit (Fabaceae): Invasora ou ruderal? Revista Arvore, 34(5), 825-833.

D'Antonio, C.M., \& Kark, S. (2002). Impacts and extent of biotic invasions in terrestrial ecosystems. Trends in Ecology and Evolution, 17, 202-204.

Fine, P. (2002). The invasibility of tropical forest by exotic plants. Journal of Tropical Ecology, 18, 687-705.

Fônseca, N.C., Albuquerque, A.S., Leite, M.J., \& Lira, C.S. (2016). Similaridade florística e colonização biológica de Prosopis juliflora [(Sw) DC] ao longo do Rio Paraíba. Pesquisas Agrárias e Ambientais, 6, 392-397.

Hedja, M., Pyšek, P., \& Jarošik, J. (2009). Impact of invasive plants on the species richness, diversity and composition of invaded communities. Journal of Ecology, 97, 393-403.

Horowitz, C., Martins, C.R., \& Machado, T. (2007). Espécies exóticas arbóreas, arbustivas e herbáceas que ocorrem nas zonas de uso especial e de uso intensivo do Parque nacional de Brasília: diagnósticos e manejo. Brasília, Brasil: Ministério do Meio Ambiente.

Hulme, P.E., Pyšek, P., Jarošik, J., Pergl, U., Schaffner, U., \& Vilà, M. (2013). Bias and error in understanding plant invasion impacts. Trends in Ecology and Evolution, 28, 212-218.

Kersten, R.A., \& Galvão, F. (2011). Suficiência amostral em inventários florísticos e fitossociológicos. In J.M. Felfili, P.V. Eisenlohr, M.M. Melo, L.A. Andrade, \& J.A. Neto-Meira (Eds.), Fitossociologia no Brasil: Métodos e estudos de casos (pp. 156-173). Brasil: Editora UFV.

Laurance, W.F., \& Bierregaard, R. (1997). Tropical forest remnants: Ecology, management and conservation 
of fragmented communities. Chicago, United States of America: University of Chicago Press.

Laurance, W.F., \& Vasconcelos, H.L. (2009). Consequências ecológicas da fragmentação florestal na Amazônia. Oecologia Brasiliensis, 13(3), 434-451.

Leão, C., Almeida, W., Dechoum, M., \& Ziller, S. (2011). Espécies exóticas invasoras no Nordeste do Brasil: contextualização, manejo e políticas públicas. Recife, Brasil: CEPAN.

Moro, M.F., \& Martins, F.R. (2011). Métodos de levantamento do componente arbóreo-arbustivo. In J.M. Felfili, P.V. Eisenlohr, M.M. Melo, L.A. Andrade, \& J.A. Neto-Meira (Eds.), Fitossociologia no Brasil: Métodos e estudos de casos (pp. 174-212). Brasil: Editora UFV.

Moro, M.F, Souza, V.C., Oliveira-Filho, A.T. de, Queiroz, L.P. de, Fraga, C.N. de, Rodal, M.J.N., ... Martins, F.R. (2012). Alienígenas na sala: o que fazer com espécies exóticas em trabalhos de taxonomia, florística e fitossociologia? Acta Botanica Brasilica, 26(4), 991-999.

Mueller-Dombois, D., \& Ellenberg, H. (1974). Aims and Methods of Vegetation Ecology. New York, United States of America: Wiley.

Munhoz, C.B., \& Araújo, G.M. (2011). Métodos de amostragem do estrato herbáceo-subarbustivo. In J.M. Felfili, P.V. Eisenlohr, M.M. Melo, L.A. Andrade, \& J.A. Neto-Meira (Eds.), Fitossociologia no Brasil: Métodos e estudos de casos (pp. 213-230). Brasil: Editora UFV.

Oliveira, A.N., \& Amaral, I.L. (2004). Florística e fitossociologia de uma floresta de vertente na Amazônia Central, Amazonas, Brasil. Acta Amazonica, 34, 21-34.

Parker, I.M., Simberloff, D., Londsale, W.M., Goodell, K., Wonham, M., Kareivs, P., ... Goldwasser, L. (1999). Impact: Toward a framework for understanding the ecological effects of invaders. Biological Invasions, 1(1), 3-19.

Pinheiro, E.S., Martinot, J.F., Cavalcante, D.G., Macedo, M.A., Nascimento, A.Z.A., \& Marques, J.P.C. (2010). Paisagem, estrutura e composição florística de um parque urbano em Manaus, Amazonas, Brasil. Rodriguésia, 61(3), 531-549.

Pivello, V.R. (2011). Invasões Biológicas no Cerrado Brasileiro: Efeitos da Introdução de Espécies Exóticas sobre a Biodiversidade. Retrieved from http://ecologia.info/cerrado.htm

Primack, R.B., \& Rodrigues, E. (2001). Biologia da conservação. Londrina, Brasil: Editora Planta.

Pyšek, P., Jarošik, V., Hulme, P., Hedja, M., Schaffner, U., \& Vilà, M. (2012). A global assessment of invasive plant impacts on resident species, communities and ecosystems: the interaction of impact measures, invading species and environment. Global Change Biology, 18(5), 1725-1737.

Ribeiro, J., Hopkins, M., Vicentini, A., Sothers, C., Costa, M., Brito, J., ... Procópio, L. (1999). Flora da Reserva Ducke: Guia de identificação das plantas vasculares de uma floresta de terra firme na Amazônia Central. Manaus, Brasil: INPA-DFID.

Ricciardi, A., Hoopes, M., Marchetti, M., \& Lockwood, L. (2013). Progress toward understanding the ecological impacts of nonnatives species. Ecological Monographs, 83(3), 263-282.

Sampaio, A.B., \& Schmidt, I.B. (2013). Espécies exóticas invasoras em unidades de conservação federais do Brasil. Biodiversidade Brasileira, 3(2), 32-49.

Santana, A., \& Encinas, I. (2008). Levantamento das espécies exóticas arbóreas e seu impacto nas espécies nativas em áreas adjacentes a depósitos de resíduos domiciliares. Revista Biotemas, 21(4), 29-38.

Sax, D.F., Stachowicz, J.J., Brown, J.H., Bruno, J.F., Dawson, M.N., Gaines, S.D., ... Rice, W.R. (2007). Ecological and evolutionary insights from species invasions. Trends in Ecology and Evolution, 22(9), 465-471.

Silva, A.F., \& Silva-Forsberg, M.C. (2015). Espécies exóticas invasoras e seus riscos para a Amazônia Legal. Scientia Amazonia, 4(2), 114-124.

Siqueira, J.C. (2006). Bioinvasão vegetal: dispersão e propagação de espécies nativas e invasoras exóticas no campus da Pontifícia Universidade Católica do Rio de Janeiro (PUC-RIO). Pesquisas Botânicas, 57, 319-330.

Souza, V.C., \& Lorenzi, H. (2008). Botânica Sistemática. Guia ilustrado para identificação das familias de fanerógamas nativas e exóticas no Brasil, baseado no $A P G$ II. São Paulo, Brasil: Nova Odessa.

The Horus Institute National Invasive Alien Species Database (2017). Base de dados de espécies exóticas invasoras do Brasil. Retrieved from http:// bd.institutohorus.org.br/www

Williamson, M., \& Filter, A. (1996). The characters of successful invaders. Biological Conservation, 78, 163-170.

Ziller, S.R. (2000). Plantas exóticas invasoras: a ameaça da contaminação biológica. Revista Ciência Hoje, 30, 77-79.

Ziller, S.R. (2006). Espécies exóticas da flora invasoras em unidades de conservação. In J.B. Campos, M.G. Tossulino, \& C.R. Muller (Eds.), Unidades de conservação: Ações para a valorização da biodiversidade (pp. 34-52). Brasil: Instituto Ambiental do Paraná. 